\title{
Subversive Humanitarianism: Rethinking Refugee Solidarity Through Grass-Roots Initiatives
}

\author{
Robin Vandevoordt*
}

\section{INTRODUCTION}

Since the summer of 2015 , new chapters have been written in the history of humanitarianism. Across Europe, hundreds of thousands of citizens provided stopgap help to newly arriving refugees. Some set up makeshift shelters and distributed food, clothes and medicines, while others arranged language classes, socio-administrative counselling hubs, or organised a series of welcoming socio-cultural events. So how do these civil initiatives differ from their professional counterparts, both in terms of their principles and their practices?

This article takes as its starting point one of humanitarianism's most pertinent critiques. No matter how benevolent its intentions, humanitarian support always carries with it an element of repression. ${ }^{1}$ As benefactors are assumed to have the resources and expertise those receiving aid are lacking, the latter tend to be reduced to bodies that need to be fed, cared for or represented by others. ${ }^{2}$ It is precisely because humanitarians set out to save lives, that they tend to misrecognise the socio-political subjectivities of the people they are trying to help. Over the last few decades, several scholars have therefore explored the conditions that would allow such subjectivities to be recognised within humanitarian settings. ${ }^{3}$ Some have suggested that

\footnotetext{
*Refugee Studies Centre, Oxford University. E-mail: robin.vandevoordt@qeh.ox.ac.uk. This paper has benefitted greatly from feedback after presentations at the Refugee Studies Centre (Oxford University), CENDEP (Oxford Brookes University) and the International Humanitarian Studies Association in The Hague. I also ow many thanks to my interlocutors at the Citizen Platform, Anika De Praetere and Gert Verschraegen. The research for this essay was made possible by the financial support from the Flemish Research Council (FWO) and an Early Career Fellowship funded by the Swiss Federal Department of Foreign Affairs.

${ }^{1}$ M. Agier, Managing the Undesirables. Refugee Camps and Humanitarian Government, London, Polity Press, 2011; D. Fassin, Humanitarian Reason: A Moral History of the Present, Los Angeles, University of California Press, 2011; B. Harrell-Bond, Imposing Aid: Emergency Assistance to Refugees, Oxford, Oxford University Press, 1986; G. Verdirame \& B. Harrell-Bond, Rights in Exile: Janus-Faced Humanitarianism, Oxford, Berghahn Books, 2005.

${ }^{2}$ L. Malkki, "Speechless Emissaries: Refugees, Humanitarianism, and Dehistoricization”, Cultural Anthropology, 11(3), 1996, 377-404; T. Scott-Smith, "Control and Biopower in Contemporary Humanitarian Aid: The Case of Supplementary Feeding", Journal of Refugee Studies, 28(1), 2014, 21-37.

${ }^{3}$ Agier, Managing the Undesirables; C. Brun, "There Is No Future in Humanitarianism: Emergency, Temporality and Protracted Displacement", History and Anthropology, 27(4), 2016, 393-410; N. Millner, "From "Refugee" to "Migrant" in Calais Solidarity Activism: Re-Staging Undocumented Migration for a Future Politics of Asylum", Political Geography, 30(6), 2011, 320-328; K. Rygiel, "Bordering Solidarities: Migrant Activism and the Politics of Movement and Camps at Calais", Citizenship Studies, 15(1), 2011, 1-19; K. Rygiel, "Politicizing Camps: Forging Transgressive Citizenships in and through Transit", Citizenship Studies, 16(5-6), 2012, 807-825; N. Sigona, "Campzenship: Reimagining the Camp as a Social and Political Space", Citizenship Studies, 19(1), $2015,1-15$.
} 
the notion of solidarity might serve as a radical alternative to humanitarianism's core principles of neutrality and impartiality. ${ }^{4}$ Rather than refraining from taking sides, these authors argue, humanitarians should "stand in solidarity with" forced migrants. And instead of caring for, they should at least attempt to "work with" them in pursuing their cause.

This article seeks to push this line of thought one step further by exploring how such an alternative look likes on the ground. To do so it seems useful, as suggested by Myriam Ticktin in her review of the field, to focus on grass-roots initiatives' potential for political innovation. ${ }^{5}$ Empirically, I therefore build on three types of data. First, I draw on my ongoing ethnographic with the Brussels-based Citizen's Platform for the Support of Refugees, which emerged as a civil initiative in 2015 and has since developed into a large, volunteer-based organisation providing emergency shelter, socio-legal counselling and socio-cultural support to forced migrants in and around Brussels. Second, I draw upon secondary ethnographic data on similar initiatives that have recently been established across Europe. Third, I systematically compare these initiatives with two of the most paradigmatic cases of humanitarian organisations: the International Committee of the Red Cross (ICRC) and Médecins Sans Frontières (MSF).

Theoretically, this essay tries to rethink the politics of refugee solidarity by developing an ideal-typical notion of subversive humanitarianism. ${ }^{6}$ Many civil initiatives supporting refugees have indeed subverted not only the dominant political order - of a world divided into Nation-States - but also the social order through which humanitarians tend to operate. I suggest seven dimensions through which the subversive features of humanitarian action can be compared across time and space. To do so I draw not only on critical ethnographies of humanitarian action, ${ }^{7}$ but also on studies of pro-migrant mobilisation that have focused primarily on protests, social movements and civil disobedience. ${ }^{8}$ These should help us grasp

\footnotetext{
${ }^{4} \mathrm{~K}$. Rozakou, "Solidarians in the Land of Xenios Zeus: Migrant Deportability and the Radicalization of Solidarity", in D. Dalakoglou \& G. Agelopoulos (eds.), Critical Times in Greece. Anthropological Engagements with the Crisis, London, Routledge, 2018, 188-201; T. Scott-Smith, "Humanitarian Dilemmas in a Mobile World", Refugee Survey Quarterly, 35(2), 2016, 1-21.

${ }^{5}$ M. Ticktin, "Transnational Humanitarianism", Annual Review of Anthropology, 43, 2014, 273-289.

${ }^{6}$ This is not to say, of course, that humanitarian actions or actors should be divided into rigid, mutually exclusive categories. Instead, the subversive character of humanitarian action is best conceived as a continuum comprising several dimensions that more often not contradict one another. This article simply suggests a number of focal points through which particular actions can be usefully compared.

${ }^{7}$ Agier, Managing the Undesirables; Fassin, Humanitarian Reason; Harrell-Bond, Imposing Aid; M. Ticktin, Casualties of Care: Immigration and the Politics of Humanitarianism in France, Los Angeles, University of California Press, 2011.

${ }^{8}$ I. Ataç, K. Rygiel \& M. Stierl, "Introduction: The Contentious Politics of Refugee and Migrant Protest and Solidarity Movements: Remaking Citizenship from the Margins", Citizenship Studies, 20(5), 2016, 527-544; D. Della Porta (ed.), Solidarity Mobilizations in the 'Refugee Crisis': Contentious Moves, London, Springer, 2018;
} 
some of the political aspects of civil action that have been less visible in studies of humanitarianism.

\section{FROM SPEAKING OUT TO CIVIL DISOBEDIENCE}

In a sense, all humanitarian actions are subversive. By providing aid to anyone in need, rather than to members of specific political, ethnic or religious communities, humanitarians create a state of exception in which particular subjectivities are temporarily replaced with a universalist notion of a shared humanity. ${ }^{9}$ This is perhaps nowhere as clear as in the mythical-historical foundation of modern humanitarianism. When Henry Dunant witnessed the horrendous battle of Solferino in 1859 , he was shocked to find that wounded soldiers only received medical care if their survival was of strategic importance to their respective armies. ${ }^{10}$ In the following years, Dunant took the lead in a series of initiatives that ultimately led to the establishment of the ICRC and International Humanitarian Law. In both, the principles of impartiality (helping those in need irrespective of their identity) and neutrality (not taking sides) were enshrined as the guiding principles of humanitarian action. As they defy political affiliations, these principles implicitly "suggest a limit to the sovereignty" of Nation-States. ${ }^{11}$

Yet there are crucial variations in how humanitarian actors relate to national sovereignty. To the Red Cross, saving lives works best by ensuring the trust of the actors involved. Hence it strictly adheres to International Humanitarian Law, which ultimately works through the institution of the Nation-State. And it prefers cooperation over conflict, even if this means making compromises with actors that block access to those in need, or that are complicit in creating the crisis in the first place. To MSF, by contrast, "speaking out" against such actors is at least as important as gaining trust. In their view, humanitarian action sometimes requires taking a stand. In the early 1970s MSF emerged out of a group of medical practitioners and journalists who had grown dissatisfied with the Red Cross' strict adherence to the principle of neutrality. Some of its founders had been part of a Red Cross mission into Nigeria, to provide

P. Nyers \& K. Rygiel (eds.), Citizenship, Migrant Activism and the Politics of Movement, London, Routledge, 2012.

${ }^{9}$ M. Barnett \& T.G. Weiss (eds.), Humanitarianism in Question: Politics, Power, Ethics, Boston, Cornell University Press, 2008; A. De Waal, "The Humanitarians' Tragedy: Escapable and Inescapable Cruelties", Disasters, 34, 2010, 130-137.

${ }^{10}$ As a deeply religious man, Dunant was at least equally concerned with soldiers' being able to receive the final sacraments. In that sense, there is a more sustained critique of humanitarianism that sees it as humanising, and thereby implicitly normalising, death, rather than acting against it. P. Redfield, Life in Crisis: The Ethical Journey of Doctors without Borders, Berkeley, University of California Press, 2013.

${ }^{11}$ P. Redfield, "The Impossible Problem of Neutrality", in E. Bornstein \& P. Redfield (eds.), Forces of Compassion. Humanitarian Reason between Ethics and Politics, Santa Fe, School for Advanced Research Press, 2011, 56. 
medical care to the victims of its civil war. On the ground, they witnessed how the Nigerian Government denied access to the secessionist Biafra areas that were most heavily struck by famine and disease. In line with the principle of neutrality and International Humanitarian Law, the Red Cross continued to pursue a dialogue with both sides, taking care to respect state sovereignty in their actions on the ground and maintain discretion in their public statements. ${ }^{12}$ Yet to some of the medics present, this meant becoming complicit to the Nigerian Government that was responsible for causing the crisis in the first place. After being joined by other practitioners and journalists, these medics later went on to found MSF as an organisation that vowed to publicly take a stand whenever necessary.

Over time, MSF developed two sets of strategies to "speak out", one more radical than the other. First, through press statements, research reports and targeted campaigns, the organisation publicly denounces actors that are either complicit in causing human suffering or impede humanitarians' access to areas of need. Second, when no other options are available, MSF threatens to withdraw from the scene of suffering. ${ }^{13}$

This is perhaps best illustrated by how MSF dealt with the Ethiopian famine crisis in the mid-1980s. While most humanitarian organisations welcomed the funds raised by Band Aid and other humanitarian media events, MSF desperately tried to make clear that the famine resulted from a political conflict in which the Ethiopian Government played a central role. By complying to the conditions of the Ethiopian Government, furthermore, most of the humanitarian aid coming from the West actually contributed to conflict that led to famine in the first place. MSF gradually increasing its confrontational tone, and ultimately threatened to leave, before being expelled by the Ethiopian Government. ${ }^{14}$ This strategy, to be sure, should be understood as a last resort, a weapon of the weak. In a situation where MSF's practitioners felt forced to become complicit with the suffering they sought to address, to them, the appropriate response seemed to be the most radical one: to step away in a final attempt to attract the public's attention.

Some of the recent civil initiatives supporting refugees seemed to have developed a related but distinct strategy. By continuing to provide support to refugees in spite of this support being discursively and legally criminalised, they engaged in acts of "civil disobedience."15

\footnotetext{
${ }^{12}$ Redfield, Life in Crisis; Scott-Smith, "Humanitarian Dilemma's in a Mobile World".

${ }^{13}$ Redfield, "The Impossible Problem of Neutrality"; E. Weizman, The Least of All Possible Evils. Humanitarian Violence form Arendt to Gaza, London, Verso Press, 2011.

${ }^{14}$ Weizman, The Least of All Possible Evils.

15 D. Della Porta, "Contentious Moves: Some Conclusions", in D. Della Porta (ed.), Solidarity Mobilizations in the 'Refugee Crisis': Contentious Moves, London, Springer, 2018, 325-448; Milner, "From Refugee to Migrant".
} 
Apart from countries such as Sweden and Germany, where national governments publicly welcomed refugees and praised the citizens supporting them, most initiatives swam against the political tide. Their governments opposed the arrival of refugees and tried to discourage them from entering their territory or, if they had already done so, urged them to travel further. Over time, more and more governments also tried to discourage citizens from helping refugees. As their citizens continued to do so, they began to criminalise such support, both in discourse and in practice. In countries as diverse as Belgium, Denmark, Switzerland, France, Italy and Greece, individual volunteers providing stopgap help (food, clothes, shelter) have been controversially arrested on the charge of human smuggling. ${ }^{16}$

In most places, however, citizens continued to support refugees. If anything, their governments' efforts to criminalise civil solidarity had the opposite effect of stirring their indignation, motivating them even more to demonstrate their hospitality. ${ }^{17}$ What is perhaps most remarkable, is that in the most heavily disputed sites, it was civil initiatives, rather than professional non-governmental organisations (NGOs), that did the bulk of the work. This has been the case most famously, of course, in Greece, where the absence of national and international organisations stood in stark contrast with the solidarity from both the local population ${ }^{18}$ and the large numbers of volunteers and activists swaying in from across the globe. Similarly, in the informal camps in Calais and Grande-Synthe too, MSF and Doctors of the World made a rather hesitant, late entrance, whilst most other NGOs simply remained absent as the French Government refused to admit the conditions in the camps as constituting a humanitarian emergency. ${ }^{19}$ At the Mediterranean Sea, as thousands risked their lives to reach

\footnotetext{
${ }^{16}$ In reality, of course, the picture is more complex than simply acting with or against 'the State' as such. In many cases, civil initiatives who went against national state actors, did so with the support of municipal authorities. This was also the case with the Citizen's Platform: it acquired support from municipality of Brussels and adjacent municipalities, both passively - in terms of less active police actions - and actively - in terms of financial and material support to set up a collective shelter for transit migrants. See: R. Vandevoordt, "Eroding rights, crafting solidarity? Shifting dynamics in the state-civil society nexus in Flanders and Brussels," Social Inclusion, 7(2), In Press, xx-xx. Similarly, in France the respective mayors of Grande-Synthe and Paris have put in efforts to provide (better) accommodation for newly arriving immigrants irrespective of their aspirations to migrate further. Hence an argument can be made that urban and municipal governments can be crucial, contentious site of support for migrants, even when national governments speak out against doing so. See e.g. V. Bontemps, C. Makaremi \& S. Mazouz, Entre accueil et rejet: Ce que les villes front aux migrants, Paris, Le passager clandestin, 2018.

${ }^{17}$ Vandevoordt, "Eroding rights, crafting solidarity?"; M. Feischmidt \& I. Zakarias, "Politics of Care and Compassion: Civic Help for Refugees and its Political Implications in Hungary - A Mixed-Methods Approach", in M. Feischmidt, L. Pries \& C. Cantat (eds.), Refugee Protection and Civil Society in Europe, London, Palgrave MacMillan, 2019, 59-99; L. Zamponi, "From Border to Border: Refugee Solidarity Activism in Italy Across Space, Time and Practices", in D. Della Porta (ed.), Solidarity Mobilizations in the 'Refugee Crisis': Contentious Moves, London, Springer, 2018, 99-124.

${ }^{18}$ Rozakou, "Solidarians in the Land of Xenios Zeus."

${ }^{19}$ E. Sandri, "'Volunteer Humanitarianism': Volunteers and Humanitarian Aid in the Jungle Refugee Camp of Calais", Journal of Ethnic and Migration Studies, 44(1), 2018, 65-80.
} 
Europe, MSF long seemed paralysed by internal debates on whether or not to intervene - and continued to struggle with this puzzle long after they decided to embark on a mission. ${ }^{20}$

The contrast between professional NGOs' hesitancy and citizens' agility was more than a matter of logistical efficiency. As Tom Scott-Smith notes, one of the more pertinent reasons for this hesitant state of mind is that "speaking out" does not sit comfortably with the principle of neutrality - which remains a key imperative to most humanitarian organisations, including the more vocal ones such as MSF. ${ }^{21}$ Neutrality, he writes, "involves maintaining a distance from political disputes and refraining from any act that might be seen as advancing the interests of one side at the expense of another". Yet "speaking out usually involves 'taking sides' in some way", ${ }^{22}$ While MSF has always advocated to transcend borders to provide care to those in need, they were now faced with a situation where borders were actually causing the suffering they sought to address. It was the first time in its history, that MSF had to denounce European governments this explicitly. This pushed the inherent contradictions between impartiality (helping those in need) and neutrality (not taking sides) yet one step further. Perhaps understandably, "[e]xplicitly breaking the law remain[ed] a step too far for most humanitarian agencies". 23

Civil initiatives, by contrast, seemed less restricted by the shackles of these humanitarian principles. In a recent article Maurice Stierl describes how four German families set up Sea-Watch, a rescue operation in the Mediterranean Sea. ${ }^{24}$ In contrast to MSF, which only gradually adopted a more confrontational stance towards the European border forces, SeaWatch expressed a more unequivocally political vision from the very start. According to them, the loss of lives at sea was partly a consequence of concrete decisions by different European governments - a conclusion MSF publicly arrived at only after its frustrations had mounted over time. They were less bound, it seems, by dilemmas of balancing their neutrality with the imperative to "speak out".

Similarly, the volunteers of the Citizen's Platform in Brussels supported refugees in whatever way they could and continued to do so even if this meant acting against the discourses and actions of their own governments. Since the summer of 2017, about 1,000 migrants had been stuck in Brussels. Many tried to reach the UK and were driven into Brussels by incessant

\footnotetext{
${ }^{20}$ H. Del Valle, "Search and Rescue in the Mediterranean Sea: Negotiating Political Differences", Refugee Survey Quarterly, 35(2), 2016, 22-40.

${ }^{21}$ Scott-Smith, "Humanitarian Dilemmas in a Mobile World"

${ }^{22}$ Ibid., 6.

${ }^{23}$ Ibid., 10. See also Del Valle, "Search and Rescue in the Mediterranean Sea"; I. Kotsioni, "Detention of Migrants and Asylum-Seekers: The Challenge for Humanitarian Actors", Refugee Survey Quarterly, 35(2), 2016, 41-55.

${ }^{24}$ M. Stierl, “A Fleet of Mediterranean Border Humanitarians”, Antipode, 50(3), 2018, 704-724.
} 
police actions in Calais and Paris. While the Government conceived of these migrants as "illegal" or "transit migrants" as they were unwilling or unable to claim asylum in Belgium, the Citizen's Platform considered them as refugees. In January 2018, federal Belgian police forces intensified their patrolling actions to drive out and arrest migrants staying in public places such as parks and train stations. On Friday 25 January, the Citizen's Platform received tips from within the police that a large action was to take place one day later, in a particular park in Brussels. In response, the Citizen's Platform launched several calls among its members informing them about the impeding actions. By the time the police arrived, all migrants had been evacuated from the area. In their place, more than 3,500 citizens formed a human chain around the park. Rather than adhering to principles of neutrality, these citizens were standing in solidarity with refugees. Like their counterparts at the Mediterranean, they went beyond speaking out: if providing basic humanitarian support to refugees required them to act in civil disobedience, they were willing and ready to do so.

\section{RECONSTITUTING SOCIAL SUBJECTS}

Humanitarian action creates particular subjects. While humanitarians are easily portrayed as altruistic heroes sacrificing the comfort of their daily lives for missions in disaster-struck areas, ${ }^{25}$ those receiving aid risk being defined as passive victims incapable of caring for themselves. Drawing on critical studies of humanitarian action, two subjectification processes seem particularly pertinent. ${ }^{26}$ First, because humanitarians focus on saving lives, they tend to reduce those "being saved" to instances of bare life, disregarding their social and political subjectivities. Anthropologists like Lisa Malkki, ${ }^{27}$ Didier Fassin $^{28}$ and Myriam Ticktin ${ }^{29}$ have documented how forced migrants' bodies are sometimes perceived as more reliable sources of truth of the abuse they have suffered, rather than the testimonies they share and the stories they tell. In that case, forced migrants are primarily approached through their physical, biological needs, rather than their lived experiences as social and political subjects. As Didier Fassin

\footnotetext{
${ }^{25}$ L. Malkki, The Need to Help. The Domestic Arts of International Humanitarianism, Durham, Duke Press, 2015. ${ }^{26}$ A crucial question that has been explored by several scholars, is how refugees themselves can express their voices, and develop strategies not only to express themselves, but to be heard as well. In this article, however, I concentrate on the different roles humanitarian actors can play in these processes of subjectification. See: Agier, Managing the Undesirables; Rygiel, "Bordering Solidarities"; Rygiel, "Politicizing Camps"; Sigona, "Campzenship". On migrant activism, see particularly the contributions in Nyers \& Rygiel, Citizenship, Migrant Activism and the Politics of Movement; I. Tyler \& K. Marciniak, "Immigrant Protest: An Introduction", Citizenship studies, 17(2), 2013, 143-156.

${ }^{27}$ Malkki, "Speechless Emissaries".

${ }^{28}$ Fassin, Humanitarian Reason.

${ }^{29}$ Ticktin, Casualties of Care.
} 
notes, humanitarian action tends to pay "more attention to the biological life of the destitute and unfortunate, the life in the name of which they are given aid, than to their biographical life, the life through which they could, independently, give a meaning to their own existence". ${ }^{30}$

A second mode of subjectification uses the categories produced by the State and/or the global refugee regime. Who is entitled to which rights then depends upon one's legal status, as defined by international treaties and national policies. While such a subjectification is of course designed to protect particular groups of people - i.e. those fleeing mass violence and/or persecution because of their membership to a particular ethnic, religious or political group - it obviously has an exclusionary side to it as well. Those who do not apply for asylum or who are rejected refugee status, for instance, have lesser rights than those who do. While the latter may be allowed to speak, as refugees, the former are degraded to bare bodies once again.

Humanitarian organisations have sometimes been accused of inadvertently reproducing statist distinctions between "illegal" 31 and "deserving" subjects. ${ }^{32}$ This is especially a risk when they either seek to maintain good relations with national governments, and/or when they endorse an explicitly a-political vision on alleviating human suffering. As an example, it is useful to look at how humanitarian NGOs are often subcontracted to provide accommodation for asylum-seekers in several European States. In Belgium, for instance, the Red Cross manages nearly half of the country's reception centres for asylum-seekers. Those whose asylum application has been rejected, or who have become undocumented migrants through whatever trajectories, rarely make use of the Red Cross, but revoke to more vocal organisations such as Doctors of the World, local parishes or civil initiatives. In a context where migration has become an increasingly contentious issue that threatens Nation-States' sovereignty, the Red Cross' preference to steer clear of controversy inclines them to limit their support to the people designated by the national government. Their strict adherence to the principle of neutrality (taking no sides) thus at least potentially hinders them from putting to practice the principle impartiality (helping those who are most in need).

As an alternative, some scholars have pleaded for a more particularist solidarity that takes as its point of departure those individuals that "are disproportionately defined by their suffering". ${ }^{33}$ This "involves taking sides, identifying and supporting a 'wronged' party", and may require humanitarians "to reject classical principles such as neutrality" to direct their

\footnotetext{
${ }^{30}$ Fassin, Humanitarian Reason, 254.

${ }^{31}$ N. De Genova, "Migrant 'Illegality' and Deportability in Everyday Life”, Annual Review of Anthropology, 31(1), 2002, 419-447.

${ }^{32}$ Fassin, Humanitarian Reason.

33 Ibid., 16.
} 
resources "towards oppressed and victimized groups". The key idea is that humanitarians "respond to people as fellow humans" rather than define people as recipients of aid or instances of bare life. ${ }^{34}$ It requires them to disregard the categories imposed by the State and/or the global refugee regime, and take seriously the story of the person standing in from of them. By doing so, humanitarians should "recognise that suffering is rooted in sociopolitical conditions, and that [their] aid has sociopolitical effects". 35

A compelling example are the Greek activists who identify themselves as "Solidarians", as described by Katerina Rozakou. ${ }^{36}$ While this notion has its roots in Athens' anarchist movements of the 1980s, today it refers to a form of support to forced migrants that includes a social and political component. Their acts of solidarity encompass basic humanitarian aid such as shelter, food and physical care, as well as legal and political support. They inform immigrants about their rights, organise political protests against detention centres and other policies set up by the Greek government, and they create social centres where immigrants and "solidarians" meet and develop their social networks.

In Brussels, the Citizen Platform has similarly tried to support undocumented migrants trying to reach the UK by informing them about their rights, organising rallies to denounce their persecution by the Belgian police forces and advocating for the establishment of a social centre offering shelter and correct and complete legal information on asylum in Europe. Initiatives such as these thus offer a more embedded form of support that does not reduce refugees to their immediate, physical needs. Instead, they reach out to refugees through a holistic approach that takes their social and political identities more seriously.

Besides subverting the humanitarian tendency to reduce recipients of aid to instances of "bare life", some civil initiatives have also tried to escape the legal categories produced by the global refugee regime. The Citizen Platform, for instance, principally does not distinguish between undocumented immigrants who had been living in Belgium for a longer period of time, who are or have already applied for asylum in Belgium, who had their fingerprints taken elsewhere in Europe, and those who were sent back from the UK to Europe or those with other trajectories. The help they provide is, at least in principle, available to anyone in need. This inclusive approach to forced migrants, every now and then led to tensions with the Red Cross' more exclusivist approach. At one point the Red Cross and the Citizen's Platform occupied different wings of an empty office building in the periphery of Brussels. On their side of the

\footnotetext{
34 Ibid., 15.

35 Ibid., 15.

${ }^{36}$ Rozakou, "Solidarians in the Land of Xenios Zeus".
} 
building, the Red Cross provided accommodation, first for homeless persons with a history of drug and alcohol abuse, and later, to asylum-seekers awaiting a place to be accommodated in a collective reception centre. On the other side of the building, the Citizen's Platform hosted migrants stranded in Brussels-North, most of whom were trying to reach the UK. As it happened that the Platform was unable to accommodate all migrants whilst the Red Cross had dozens of empty beds - which it was unable to share due to its contract with the Federal Government - tensions arose between the Platform and the Red Cross. Put simply, the humanitarian support they provided had different rationales behind them: the one more inclusive than the other.

On the one hand, the Platform thus seemed to be more inclusive than the Red Cross. Yet on the other hand, the Platform too faced challenges in deciding who to help. Throughout 2017 and 2018 tensions arose between the Platform, the undocumented migrants they supported and Brussels' homeless population. ${ }^{37}$ While the Platform occasionally opened up its facilities to homeless persons too, they felt ill-equipped to deal with some of the homeless persons who sought shelter, as they displayed signs of substance abuse and aggressive behaviour towards volunteers and migrants. As the Platform struggled to provide shelter to all the migrants that were stranded in Brussels-North, it made the difficult decision to concentrate its efforts no those who they thought were "wronged" the most by Belgian government policies. To the Platform, this was the specific group of undocumented migrants trying to reach the UK, as they were being actively pursued by the Belgian police, lacked the information to escape from their legal limbo and were excluded from the support of professional NGOs like the Red Cross.

This decision to side with those most "wronged" has remained a sensitive, painful issue for the Platform's coordinators. Yet I think it is inherent to the particularist solidarity and the holistic approach the Platform has adopted. Obviously, most professional humanitarian actors sooner or later face the dilemma of allocating its scarce resources over different groups of people in need. Yet they usually apply selection criteria that are minimal and universal: they prioritise individual who have the most urgent physical needs, irrespective of their social and political subjectivities. The Citizen Platform, however, also tries to offer legal, social and political support, and to do so they need more contextual knowledge of the problems migrants face, their previous trajectories and future aspirations. In sum, the challenges the Platform were

\footnotetext{
${ }^{37}$ Similarly, the Platform has struggled to include existing sans-papiers and their social movements. See A. De Praetere \& S. Oosterlynck, “'I Finally Found my Place': A Political Ethnography of the Maximiliaan Refugee Camp in Brussels", Citizenship Studies, 21(6), 2017, 693-709.
} 
confronted with, point to a tension that is deeply inherent to a more particularist sense of solidarity: if social and political subjects rather than bodies become the central subjects of solidarity, then it seems likely that the inclusionary range of that solidarity will be limited in turn.

Lastly, I want to draw attention to another potential side-effect of such a more politicised form of support. In different contexts, scholars have noted that activists' attempts to stimulate political mobilisation can also contain an element of repression. Laura Agustin, for instance, has documented how Spanish social workers that tried to reach out to sex workers, faced unexpected challenges. ${ }^{38}$ The women they tried to support rejected some of the political ideas which they felt their supporters were imposing upon them - this included a struggle over the use of the term "sex workers". Similarly, as Rozakou noted, there is a tendency among the more politically oriented civil initiatives to mobilise refugees into protests. ${ }^{39}$ Yet as we know from a growing body of ethnographic work, forced migrants may reject being labelled "refugee" for various reasons. ${ }^{40}$ In that sense, their identification with a collective cause, even if it is their own, is not something that should be too readily assumed. Their reconstitution as social and political subjects, ultimately depends upon their own intentions and actions.

\section{CONTENDING SYMBOLIC SPACES}

Refugee camps are sometimes conceived as exemplary sites where some of humanitarianism's worst tendencies are magnified. Camps are often set up with the double goal of providing shelter and whilst containing its residents from the host society. ${ }^{41}$ They are constructed, as Agier notes, as symbolic deserts, "outside the place and time of the commonplace, ordinary and predictable world". ${ }^{42}$ They are arid environments "in which conversation and freedom are disturbing and troublesome. The common space between refugees, their 'world', is not desired nor foreseen. In its place is just an empty space, and so it remains, despite the recommencement of life that is attempted within it." 43

\footnotetext{
${ }^{38}$ L. Agustín, "Sex and the Limits of Enlightenment: The Irrationality of Legal Regimes to Control Prostitution", Sexuality Research \& Social Policy, 5(4), 2007, 73.

39 Rozakou, "Solidarians in the Land of Xenios Zeus".

${ }^{40}$ G. Cole, "Beyond Labelling: Rethinking the Role and Value of the Refugee 'Label' through Semiotics", Refugee Survey Quarterly, 31(1), 2018, 1-21; L. Malkki, Purity and Exile: Violence, Memory and National Cosmology among Hutu Refugees in Tanzania, Chicago, Chicago University Press, 1995; R. Zetter, "More Labels, Fewer Refugees: Remaking the Refugee Label in an Era of Globalization", Journal of refugee studies, 20(2), 2007, 172192.

${ }^{41}$ Agier, Managing the Undesirables; Malkki, Purity and Exile; K. McConnachie, "Camps of Containment: A Genealogy of the Refugee Camp", Humanity, 7(3), 2016, 397-412.

${ }^{42}$ Agier, On the Margins of the World, 40.

${ }^{43}$ Ibid., 39-40.
} 
Many of the recent civil initiatives to support refugees seemed to have directly and indirectly challenged this tendency of humanitarian aid to contain the undesirable parts of the population. Several scholars have drawn attention to the rise of "border spectacles" both in Europe and elsewhere: where police forces spectacularly demonstrate their toughness vis-à-vis immigrants trying to enter the territory. ${ }^{44}$ By doing so, police officers are staged as heroic guardians of national security, whilst immigrants appear as criminals crossing the symbolic line of legality. Conversely, many civil initiatives have engaged in similar strategies by rendering their solidarity with arriving immigrants publicly visibly, thereby re-subjectifying them as people endowed with the right to be there and receive basic humanitarian care. This has been the case, of course, well before 2015 in places such as Calais ${ }^{45}$ and Vienna, ${ }^{46}$ but has afterwards emerged along the routes migrants took across Europe. In these border-like places, citizens and refugees transformed abject, invisible places into symbolically significant sites of contentious solidarity. ${ }^{47}$

Students of social movement have often addressed the latter's ability to "strategically manipulate, subvert and re-signify places that symbolise the priorities and imaginaries they are contesting". ${ }^{48}$ In an attempt to attract media attention and convey their message to a broader audience, social movements use sites that symbolise what they are contending - this was embodied perhaps most clearly by the "Occupy Wall Street" movement as it symbolically reconquered power from the wealthiest 1 per cent. The recent wave of civil initiatives supporting refugees, however, seemed to engage in related yet distinct modes of contention. First, these strategies were not so much consciously designed to attract media attention, as they were side-effects to providing humanitarian support wherever it was needed. It was only in response to government's attempts to drive migrants and the civil support they received out of the public eye, that these initiatives engaged in strategies to keep these sites of solidarity intact. Second, and relatedly, these initiatives often seemed to focus less on public places that were already symbolically significant, and more on places that were initially rather insignificant to broader public.

\footnotetext{
${ }^{44}$ C. Cantat, "The Hungarian Border Spectacle: Migration, Repression and Solidarity in two Hungarian Border Cities", Centre for Policy Studies Working Paper, Budapest, Central European University, 2017/3; R. Van Reekum, "The Mediterranean: Migration Corridor, Border Spectacle, Ethical Landscape", Mediterranean Politics, 21(2), 2016, 336-341.

${ }^{45}$ Millner, "From Refugee to Migrant Activism"; Rygiel, "Bordering Camps"; Rygiel, "Politicizing Camps".

${ }^{46}$ I. Ataç, "'Refugee Protest Camp Vienna': Making Citizens through Locations of the Protest Movement", Citizenship Studies, 20(5), 2016, 629-646.

${ }^{47}$ Zamponi, "From Border to Border".

${ }^{48}$ H. Leitner, E. Sheppard \& M. Sziarto, "The Spatialities of Contentious Politics", Transactions of the Institute of British Geographers, 33(2), 2008, 157-172.
} 
Again, the Citizen's Platform serves as an insightful example. The Platform arose in the summer of 2015 from the Maximilian Park, a somewhat neglected park in between a poorer urban area and the Brussels North business district. Looming over the park is the World Trade Centre, home to the immigration Office, where asylum-seekers first have to register if they want to apply for asylum. As soon as they have done so, they are legally entitled to accommodation either in a collective reception centre, or an individual, "local accommodation initiative". In August that year, however, the Immigration Office struggled to register those seeking to apply for asylum, thereby leaving thousands on the streets without a right to shelter. As volunteers poured into the park with tents, clothes and food, they transformed this quiet, unremarkable place where tens of thousands of commuters pass by every day, into a powerful symbol of both the government's failure to accommodate asylum-seekers and citizens' ability to do so instead. As observers noted, those working in the park did not need to do much to make their actions visible to the mass media and the wider public: ${ }^{49}$ the mere contrast between volunteers taking action to resolve the crisis unfolding itself in front of the responsible government agencies was significant enough.

\section{SOCIAL SPACES AND PERSONAL BONDS}

Apart from making solidarity more visible, many of these civil initiatives also created social spaces where citizens and refugees encountered one another, unmediated by state agencies, professional NGOs and media representations. ${ }^{50}$ Sara de Jong and Ilker Ataç found that the Austrian civil initiatives they were studying, provided refugees with weak ties to local citizens, thus facilitating an early entry into Austrian society. ${ }^{51}$ According to Ataç, these initiatives even provided refugees who had already resided in Austria for several months, with their first proper chance to establish contact with Austrians outside of the reception centres they were staying in. ${ }^{52}$ In Belgium, initiatives such as the Citizen's Platform have created ample opportunities for such encounters to take place: in and around the Maximilian park, where volunteers organised children's classes, music workshops and football games; by launching buddy-networks in

\footnotetext{
${ }^{49}$ de Praetere \& Oosterlynck, “'I Finally Found my Place”; D. Lafaut \& G. Coene, “'Let Them In!' Humanitarian Work as Political Activism? The Case of the Maximiliaan Refugee Camp in Brussels", Journal of Immigrant \& Refugee Studies, 2018, 1-19.

${ }^{50}$ Ataç, "Refugee Camp Vienna"; K. Braun, "Decolonial Perspectives on Charitable Spaces of 'Welcome Culture' in Germany", Social Inclusion, 5(3), 2017, 38-48; L. Fleischmann \& E. Steinhilper, "The Myth of Apolitical Volunteering for Refugees: German Welcome Culture and a New Dispositif of Helping", Social Inclusion, 5(3), $2017,17-27$.

${ }^{51}$ S. de Jong \& I. Ataç, "Demand and Deliver: Refugee Support Organisations in Austria", Social Inclusion, 5(3), $2017,28-37$.

52 Ataç, "Refugee Camp Vienna".
} 
which asylum-seekers are guided by volunteers throughout their procedures; and by organising socio-cultural activities designed specifically to create such encounters.

As several scholars have noted, these social spaces occasionally gave rise to tensions and conflicts. ${ }^{53}$ Confronted with refugees claiming a sense of dignity and autonomy for themselves, volunteers sometimes became frustrated that their benevolent actions were not met with the gratitude they were due. Detailing some of these conflicts in initiatives in Hamburg, Katherine Braun nonetheless argues that even mutually frustrating encounters were sometimes able to stimulate a fruitful dialogue. ${ }^{54}$ They opened up room for dissent that challenged volunteers' initial ideas about the "others" they were helping. "It is precisely by means of such conflicts and the dissent they elicit", she concludes, that charitable spaces of hierarchical care were transformed into a "space where subjects with differing histories, geopolitical locations, and social positions interact with one another." 55

According to de Jong and Ataç, ${ }^{56}$ these social spaces were precisely what gave the initiatives they studied their radical, political character, as they broke through the pattern of what Vicki Taubig ${ }^{57}$ has described as the "organised disintegration" of the German refugee regime. This potential to create social spaces indeed contrasts with how the reception of asylum-seekers and refugees is usually regulated in Europe. In my previous research with Syrian refugees in Belgium, ${ }^{58}$ for instance, I found that most refugees who were well into their third and fourth years after arrival, had hardly established any contact with local citizens, in spite of their reported efforts. The only Belgians they had properly interacted with were professionals that were employed to do so: social workers, civic integration instructors, language teachers, labour market coaches, lawyers and medical practitioners. Again, this feeds into the earlier discussion of refugee camps as serving the indirect purpose of containing refugees, both symbolically and socially, by warehousing them into remote areas with poor transport connections, and limited access to formal social institutions such as the labour market and education. ${ }^{59}$

\footnotetext{
${ }^{53}$ Braun, "Decolonial Perspectives"; R. Vandevoordt \& G. Verschraegen, "Subversive humanitarianism and its challenges. Notes on the political ambiguities of civil refugee support," in M. Feischmidt, L. Pries \& C. Cantat (eds.) Refugee protection and civil society in Europe, Cham, Palgrave MacMillan, 2019, 101-128.

${ }^{54}$ Braun, "Decolonial Perspectives", 44.

${ }^{55}$ Ibid., 45.

${ }^{56}$ de Jong \& Ataç, "Demand and Deliver."

${ }^{57}$ V. Taubig, Totale Institution Asyl. Empirische Befunde zu alltäglichen Lebensführungen in der organisierten Desintegration, Winheim, Juventa Verlag, 2009.

${ }^{58}$ R. Vandevoordt, "Encountering Belgians. How Syrian refugees build bridges over troubled water," in E. Fiddian-Qasmiyeh (ed.) Refuge in a moving world: interdisciplinary conversations, London, UCL Press, In Press, $\mathrm{XX}-\mathrm{XX}$.

${ }^{59}$ Agier, Managing the Undesirables; McConnachie, "Camps of Containment."
} 
Instead, these civil initiatives provided both migrants and locals with a space to encounter one another directly, in spite of the differences in their formal citizenship status. While such spaces of course do not undo these differences in status, they do harbour the potential of offering a first step towards reconstituting asylum-seekers and refugees as social subjects, beyond the antinomies of insiders and outsiders. In some more subversive cases, these social encounters fed into lasting personal bonds between volunteers and refugees. In the Citizen's Platform, this was especially the case for those participating in the hosting-at-home system, whereby migrants on route to England were sheltered in the homes of volunteers. ${ }^{60} \mathrm{As}$ volunteers hosted refugees into their domestic space, many developed strongly affective ties that continue to last. Most hosts and guests referred to one another through familial, affectionate terms, such as "uncle/auntie", "brother/sister" or "nephew/niece". And they kept in touch as their guests travelled further to England, were arrested in Europe, or again needed a place to sleep a few months later. Quite often they would not even make use of the Citizen's Platform any more, to arrange an overnight stay, as hosts and guests easily found each other.

Although this hosting-at-home system may represent a somewhat extraordinary environment, the affectionate ties it fed into do seem to characterise many civil initiatives supporting refugees. Several scholars have indeed emphasised how the emotional intensity of the encounters they create, has been central to citizens' initial experiences and their motivation to continue their engagement. ${ }^{61}$ In sum, these social spaces work on two levels. On the one hand, they create an opportunity for locals and migrants to engage in face-to-face dialogue. On the other hand, they offer them an affectionate gateway into a more intensively experienced personal bond. In both cases, I argue, tentative steps are taken towards the reconstitution of refugees' social subjectivities.

\section{A RELATIONAL ETHICS OF CARE}

One of the recurrent critiques that has befallen much humanitarian work, is that it creates asymmetric power relations between providers and recipients of aid. At the root of much

\footnotetext{
${ }^{60}$ R. Vandevoordt, "A more personal shelter. How citizens are hosting forced migrants in and around Brussels," in M. Breeze \& T. Scott-Smith (eds.) Structures of protection. Rethinking refugee shelter, Oxford, Berghahn Books, In Press, xx-xx.

${ }^{61}$ U. Hammam \& S. Karakayali, "Practicing Wilkommenskultur: Migration and Solidarity in Germany", Intersections, 2(4), 2016, 69-86; S. Karakayali, "Feeling the Scope of Solidarity: The Role of Emotions for Volunteers Supporting Refugees in Germany", Social Inclusion, 5(3), 2017, 7-16; J. Kleres, "Emotions in the Crisis: Mobilising for Refugees in Germany and Sweden", in D. Della Porta (ed.), Solidarity Mobilizations in the 'Refugee Crisis': Contentious Moves, London, Springer, 2018, 209-242; Sandri, "Volunteer Humanitarianism"; O. Sutter, "'Willkommen!': Emotionale Politiken des zivilgesellschaftlichen Engagements für Flüchtende", Zeitschrift für Volkskunde, 113(1), 2017.
} 
(professional) humanitarian action lies an uncomfortable assumption of ultimate inequality, even amongst the most horizontal NGOs. ${ }^{62}$ Humanitarians seek to save lives, and to do so they act primarily as professionals. ${ }^{63}$ Medical staff, logisticians and camp managers are selected and trained to have specific skills, expertise and resources that recipients of aid are assumed to lack. Hence it makes sense to put them in control. ${ }^{64}$ As a result, humanitarian aid often appears as a gift that cannot be reciprocated, which therefore installs a relationship of forced, unilateral dependency. ${ }^{65}$

At least some civil initiatives have seemed preoccupied with ensuring that they worked as horizontally as possible. In the Citizen's Platform, volunteers repeatedly explained to us how they differed from professional humanitarians working for organisations such as the Red Cross, Caritas International and Refugee Action, who, according to the Platform's members, treated refugees as dossiers, rather than genuine persons. One of the coordinators of the Platform's then nascent buddy-project, told us that:

But we actually call it godfather and godmother, or be my friend or be my buddy, soi mon ami. It all sounds a bit stupid (laughs), but the idea is, we really want this to be horizontal relations. And godfathership still means that it's a bit vertical. And we have the idea, which doesn't mean that you can't help with administrative stuff for example, if you want to do that as a godfather or godfather than that's just fine. But it's more the idea to have horizontal relationships, in the sense of, you're equal, you're equal persons, and you meet each other as friends. So we've worked out a charter like this, for both local people and for refugees. ${ }^{66}$ (also quoted in Author and Author 2019).

My point is not that the relations between volunteers and refugees are effectively horizontal in these initiatives. There are power asymmetries in every social relation, especially if one of the actor depends on the other for his/her basic needs - several scholars have indeed described the power dynamics at play within such initiatives. ${ }^{67}$ Rather, my point is that these horizontal

\footnotetext{
${ }^{62}$ D. Fassin, "Inequality of Lives, Hierarchies of Humanity: Moral Commitments and Ethical Dilemmas of Humanitarianism", in I. Feldman (ed.), In the Name of Humanity: The Government of Threat and Care, Durham, Duke University Press, 2010, 238-255.

${ }^{63}$ Malkki, The Need to Help.

${ }^{64}$ M. Barnett \& T.G. Weiss, "Humanitarianism: A Brief History of the Present", in M. Barnett \& T.G. Weiss (eds.), Humanitarian Question. Politics, Power, Ethics, Ithaca/London, Cornell University Press, 2008, 1-40.

${ }^{65}$ B. Harrell-Bond, "Can Humanitarian Work with Refugees Be Humane?", Human rights Quarterly, 2002, 24(1), $51-85$.

${ }^{66}$ Also quoted in Vandevoordt \& Verschraegen, "Subversive humanitarianism and its challenges."

67 Vandevoordt \& Verschraegen, "Subversive humanitarianism and its challenges." Braun, "Decolonial Perspectives"; H. Castaneda, "Medical Aid as Protest: Acts of Citizenship for Unauthorized Im/migrants and Refugees", Citizenship Studies, 17(2), 2013, 227-240; P. Scheibelhofer, "Gender and Intimate Solidarity in Refugee-Sponsorships of Unaccompanied Young Men", in M. Feischmidt, L. Pries \& C. Cantat (eds.), Refugee Protection and Civil Society in Europe, London, Palgrave MacMillan, 2019, 193-219.
} 
relations are significant as a discourse circulating among volunteers, and as a genuine belief that guides their actions. In countless discussions, volunteers and coordinators stressed the importance of distinguishing themselves from their professional counterparts through their horizontal approach vis-à-vis the refugees they were helping.

This horizontal approach signifies a shift in the ethics that guides humanitarian action. Due to the unilateral focus on providing aid, most humanitarian ethics centres around the duties, consequences and virtues of humanitarian workers. Scholars such as Cathrine Brun ${ }^{68}$ and Alain Finkielkraut ${ }^{69}$ by contrast, have argued for a relational ethics of care that gives a central role to interpersonal relations between refugees and humanitarian workers. Such an ethics of caring about, rather than caring for, enables one to take into account local contexts and the specific biographies of humanitarian and refugees alike. In such a setting, Brun argues, "social relationships of mutuality and trust rather than dependency are foregrounded", and "people who are to be assisted in a crisis are not strangers" but "part of the wider relationships" in which both lead their lives. ${ }^{70}$

This aptly describes the ethics guiding most of the Citizen Platform's members. As I mentioned in the previous section, volunteers and refugees often developed informal, affectionate ties with one another. Regardless of the evident power asymmetries they give rise to, these ties did allow for some degree of reciprocity and mutuality. While hosts did not expect their guests to reciprocate their hospitality, for instance, the latter sometimes attempted to offer a "countergift" by cooking a dish typical of their homeland, spending spare time together or listening to each other's stories. These findings seem to resonate with studies of buddy schemes to support refugees in Austria ${ }^{71}$ and Germany, ${ }^{72}$ where an informal, diffuse form of reciprocity allowed for an ethics that was centred around the relationship between actors, rather than forging an unilateral dependency through the "gift" of professional humanitarian aid.

It bears repeating however, that I do not argue that these relations are effectively equal and free of power-dynamics - if anything, these forms of support will, to use Ticktin's turn of

\footnotetext{
${ }^{68}$ Brun, "There Is No Future in Humanitarianism". See also I. Feldman, “The Quaker Way: Ethical Labour ad Humanitarian Relief," American Ethnologist, 34(4), 2007, 689-705.

69 A. Finkielkraut, In the Name of Humanity. Reflections on the Twentiety Century, New York, Columbia University Press, 2000.

${ }^{70}$ Brun, "There Is No Future in Humanitarianism", 405.

${ }^{71}$ Scheibelhofer, "Gender and Intimate Solidarity."

${ }^{72}$ I. Stock, "Buddy Schemes Between Migrants and Volunteers in Germany: Transformative Potential in an Unequal Relationship?”, Social Inclusion, 7(2), 2019; S. Schmid, “Taking Care of the Other: Visions of a Caring Integration in Female Refugee Support Work”, Social Inclusion, 7(2), 2019.
} 
phrase, ${ }^{73}$ constitute different regimes of care producing different types of casualties. Rather, the point I want to make is that the discourse of horizontality that pervades initiatives like the Citizen Platform, puts in place a distinctly relational ethics of care that allows room for local contexts, individual biographies and mutual trust.

\section{PUTTING MINDS INTO MOTION}

Bearing witness, we saw earlier, has become a guiding principle to NGOs such as MsF. Through press releases, media campaigns and research reports, MsF denounces actors obstructing humanitarians' access to the field, as well as those contributing to suffering as such. In a similar vein, the Citizen's Platform continuously circulates stories of both migrants and volunteers, mainly on its closed Facebook groups and on its public website. These stories comprise demonstrations of human solidarity, as well as detailed accounts of police intimidation vis-à-vis migrants and volunteers. In addition, the Platform's coordinators use these Facebook groups - which currently count close to 50,000 members - to post reflections and analyses of Belgian Government's policy measures and politicians' statements. As these posts are widely shared and commented upon by the Platform's members, these coordinators essentially adopt a role as opinion makers. ${ }^{74}$

From that perspective, many such initiatives share some characteristics with social movements - which is evidenced by the fact that most analyses have come not from students of humanitarianism but from those studying social movements and protests. ${ }^{75}$ According to its coordinators, for instance, the Citizen's Platform's goal is twofold: besides providing humanitarian support to migrants, it also seeks to induce changes in the public's broader understanding of the politics of migration. To do so, its coordinators have drawn upon a repertoire of strategies common among social movements: they regularly call upon the Platform's members to join rallies and petitions related to their cause and, occasionally, organise such actions themselves, always in close collaboration with more established organisations.

At the same time, many of these civil initiatives have evidenced a more ambiguous relation to politics ${ }^{76}$ - which sometimes seems to have puzzled social movement scholars who

\footnotetext{
73 Ticktin, Casualties of Care.

${ }^{74}$ Vandevoordt, "A more personal shelter".

75 Ataç, Rygiel \& Stierl, "Introduction”; della Porta, Solidarity Mobilizations; E. Youkhana \& O. Sutter (eds.), "Perspectives on the European Border Regime: Mobilization, Contestation and the Role of Civil Society", Social Inclusion, 5(3), 2017.

76 Vandevoordt \& Verschraegen, "Subversive humanitarianism"; de Jong \& Ataç, "Demand and Deliver"; Feischmidt \& Zakaria, "Politics of Care and Compassion"; Fleischmann \& Steinhilper, "The Myth of Apolitical
} 
perhaps too readily assume that these initiatives are driven by political motivations. ${ }^{77}$ When I asked one of the Platform's spokespersons whether they saw themselves as political actors, he replied "We are conscious that we are [doing] politics". But the point is, he added, that "you don't have to ask people to do politics. You have to give them the opportunity to believe that they can change things."

Although such strategies were sometimes necessary, he said the Platform had little interest in manifestations, rallies or petitions that were merely symbolic. Instead, their core strategy was to engage its members into direct social action ${ }^{78}$ that served the needs of migrants and communicate this act of solidarity towards the broader public.

You know, I think people are not informed. They don't look at the news, people don't give a shit about it. The only thing they hear is one guy is saying black and one guy is saying white and pfrt! Keep on fighting guys. (But) if you just call out for more solidarity, for more support, for more humanity, then people join. And the moment you join, the moment they're in, it's done, you cannot close your eyes and go back to sleep, go back to your life.

In sum, it was through direct social action that the Citizen's Platform sought to achieve its secondary goal of increasing volunteers' political reflexivity about the European migration regime, and occasionally, draw them into more traditional forms of political actions such as rallies, petitions and letter-writing campaigns. The Platform's Facebook groups played a crucial role in this process of reflexive politicisation, as it was there that its members were regularly exposed to witnessing stories and political comments.

\section{TRANSFORMING SOCIAL LIVES AND SHARED MEANINGS}

In the Need to help, Lisa Malkki explored how professionals working for the Finnish Red Cross made sense of their humanitarian actions. Many contrasted their missions abroad with the atomised, formalised lives they led in Finland - a contrast that echoed the classical binary of things profane and sacred. Some described their missions as episodes that were "full of life", where they immersed themselves in "easier human sociality and conviviality, even in the midst of terrible circumstances". Many had become humanitarians partly because of the increased

\footnotetext{
Volunteering”; M.P. Frykman \& F. Märelä, “'Only Volunteers’? Personal Motivations and Political Ambiguities within the Refugees Welcome to Malmö Civil Initiative", in M. Feischmidt, L. Pries \& C. Cantat (eds.), Refugee Protection and Civil Society in Europe, London, Palgrave MacMillan, 2019, 291-318.

77 J. Alcalde \& M. Portos, "Scale Shift and Transnationalisation Within Refugees' Solidarity Activism. From Calais to the European Level", in D. Della Porta (ed.), Solidarity Mobilizations in the 'Refugee Crisis': Contentious Moves, London, Springer, 2018, 243-270.

${ }^{78}$ See also Zamponi, "From Border to Border".
} 
sense of urgency and significance that emerges from doing such work. In their work, Malkki notes, they sought

a partial escape from national belonging - even an escape from their mundane, workaday selves. The safe, well-ordered and in principle predictable home, the welfare society that should have met their social and material needs, had become, for some, burdensome and constraining, and emotionally cold. ${ }^{79}$

This must sound familiar to many of the citizens who got involved in refugee support. While the experiences of professions going on mission are clearly intense, ${ }^{80} \mathrm{I}$ do think citizens' engagements have had a wider and deeper transformative effect upon their lives, partly because they had received little if any previous training in working as humanitarians. For all the collective effervescence Malkki's Red Cross humanitarians seemed to experience, "they were professionals before they were humanitarians". ${ }^{81}$ They were trained as doctors, logisticians or translators and it was in those capacities that they distinguished themselves from benevolent volunteers or religious charity workers.

Whereas Malkki emphasised the contrast her professional humanitarians experienced between their daily lives and their missions, my interlocutors emphasised the transformative impact of these shared experiences upon their lives. In the first few weeks in August and September of 2015, citizens flocked in thousands to the Maximilian Park to provide stopgap help, and many continued to work there for several consecutive days, weeks or even months. They spoke of a rupture in their lives, a before and an after getting engaged. Suddenly they were spending much if not all of their spare time in the camp, where the seeds were sown for new, sometimes short-lived, sometimes possibly lifelong friendships. Tellingly, one of the Platform's coordinators recounted how she had begun by helping in the park every night after work, until the last train took her home. At the moment I spoke with her, several months after the camp had been abandoned, she was still spending most of her spare time in the Platform, helping recognised refugees find a rental accommodation, amongst others things. She mused upon the impact on her social life: "I regularly hear from my old friends that, well, hey, we're still here as well you know. Time has just flown by so quickly these last few months."

There was more to their engagement than merely a matter of time tough. Many volunteers spoke of how they lost contact with their older circle of friends, as they spent more time with friends they had encountered through the Platform and with whom they shared a number of

\footnotetext{
${ }^{79}$ Malkki, The Need to Help, 8.

${ }^{80}$ Ibid.; S. Roth, The Paradoxes of Aid Work: Passionate Professionals, London, Routledge, 2015.

${ }^{81}$ Malkki, The Need to Help, 38.
} 
intensive experiences. Several of my interlocutors struggled to relate with the concerns of their older circles of friends. When compared to the stories they heard from migrants, as well as the suffering and the resiliency they were confronted with as migrants roamed around Brussels' streets, pursued by the police, the worries of their old friends appeared as painfully trivial.

With my friends I've got the feeling that there's a bit of a distance now, especially because in the winter, the things we have gone through there, it was really intense. Yeah (sighs). I also struggled when my friends were talking about their problems, I was like okay sure but erm (laughs), that's not really important. And I've said to myself you can't trivialise their problems, but it's difficult. There's this friend who is studying and she doesn't know what she's going to do next year. And I know it's hard if you don't know what you're going to do next year, but on the other hand, they just know so little (laughs). Scholars across Europe seem to agree that most citizens acted primarily out of a humanitarian, explicitly apolitical imperative to help refugees in need, which gradually made them more aware of the political causes creating the needs they were trying to address. ${ }^{82}$

For the first time, they witnessed from up close the discrimination and exclusion asylum-seekers and refugees are confronted with. ${ }^{83}$ Drawing on a series of German case studies, Hamann and Karakayali note that:

As many of the volunteers have middle class backgrounds, their engagement involves experiencing, sometimes for the first time in their lives, the structural violence that people of foreign backgrounds with low professional profiles face in the German welfare system. ${ }^{84}$

Similarly, many of my interlocutors spoke of how witnessing migrants experiences from up close had "opened their eyes" with respect to how Belgian institutions deal with asylumseekers, recognised refugees and undocumented migrants. Those who were active from 2017 onwards - when the focus of the Citizen's Platform shifted from recognised refugees to socalled "transit migrants" on route to England - often recounted stories of how police officers intimidated migrants both verbally and physically. Many expressed shock and disbelief that this happened today, in their country, in their streets.

\footnotetext{
${ }^{82}$ Braun, "Decolonial Perspectives"; Feischmidt \& Zakaria, "Politics of Care and Compassion"; Fleischmann \& Steinhilper, "The Myth of Apolitical Volunteering"; Sandri, "'Volunteer Humanitarianism."

${ }^{83}$ de Jong \& Ataç, "Demand and Deliver."; Fleischmann \& Steinhilper, "The Myth of Apolitical Volunteering"; Scheibelhofer, "Gender and Intimate Solidarity".

${ }^{84}$ Hamman \& Karakayali, "Practicing Wilkommenskultur", 80.
} 
These experiences often contrasted with the stories they saw in the mass media. When I asked one of my interlocutors at the Citizen's Platform's whether he looked at politics differently, he said it was actually the press that had become "troublesome" for him.

I've become much more suspicious of the media, of how they cover migration issues... What I do much more now is... I compare the news in Flanders and Wallonia, commercial and public. When I go to the park, I always watch TV when I get home, no matter how late it is, then I watch the news at the public broadcaster, then at the commercial broadcaster, and then you look at another one and another and then you're in four different worlds. It's not just the place they give issues in the news, but also the attention they give to it.... So our friends of the (public broadcaster), their ombudsmen, have received many e-mails from me over the last few months (laughed).

This man's experience was widely shared among the volunteers I spoke with: they had lost their trust in the mass media. The scenes they saw on the streets, the stories they heard from migrants and the interpretations they read on Facebook, were hard to reconcile with the reports that appeared in the media.

\section{CONCLUDING THOUGHTS}

This essay began with a simple question: how to understand the recent wave of civil initiatives in support of refugees vis-à-vis the work of professional humanitarian actors? And, more precisely, how have they changed our understanding of the political nature of humanitarian action? In response, I have suggested the ideal-typical notion of subversive humanitarian. Theoretically, this notion helps us think through a shift from a humanitarianism that transforms forced migrants into recipients of aid, to a form of solidarity that allows more room for their socio-political subjectivities. Empirically, I operationalised the notion of subversive humanitarianism by suggesting seven dimensions through which humanitarian actions can be usefully compared across time and space: civil disobedience; reconstituting social subjects; contending symbolic places; constructing social spaces and personal bonds; assuming equality; putting minds into motion; and transforming individual lives.

Like every heuristic concept, "subversive humanitarianism" has its shortcomings. As an ideal type, in particular, it risks drawing too much attention to the differences that set cases 
apart, instead of detailing their particular complexities or the interconnections between them. ${ }^{85}$ What I have presented here as ideal-typical features of a subversive character, is in reality always more complex, and replete with challenges and strategies. Hence at least some professional humanitarian organisations also try to "put minds into motion" and "construct social spaces", while socially subversive civil initiatives may politically cooperate with local state authorities. In a separate paper, I therefore highlight some of the dimensions described here in a more balanced manner, that emphasises the challenges the Citizen's Platform has been faced with, and how they tried to deal with them. ${ }^{86}$

I have similarly drawn less attention to the connections between different cases. It would be particularly interesting to see not only how these relations develop between civil initiatives, but also how they engage with professional NGOs and government agencies. Hence some of the tensions with respect to provider/recipient relations can be analysed fruitfully by examining how initiatives such as the Citizen's Platform work together with organisations such as MsF or Médecins de Monde. And lastly, I am aware that my argument has been overly Eurocentric, both in its theoretical focus on so-called modern humanitarianism, and in its empirical focus on civil solidarity initiatives in Europe. This lack is particularly important as more than 80 per cent of forced migrants worldwide are sheltered in the global South. More attention should indeed be given to instances of what has recently been termed "South-South humanitarianism". 87

In spite of these shortcomings, I do think the notion of subversive humanitarian can be useful as long as it is used to the limited purposes ideal-types are meant to serve: to enable comparison across cases by drawing out some of their key characteristics. Hence it could serve as a tool to compare how professional NGOs and civil initiatives respond to particular emergencies. Or it could help to study differences and commonalities with earlier waves of civil refugee solidarity in Europe, and in the global South. In all these cases, it is indeed crucial to examine how we can stand in solidarity with forced migrants as social subjects, rather than reducing them to instances of bare life.

\footnotetext{
85 cf. G. Bhambra, Rethinking Modernity: Postcolonialism and the Sociological Imagination, New York, Springer, 2017.

${ }^{86}$ Vandevoordt \& Verschraegen, "Subversive humanitarianism and its challenges."

87 E. Fiddian-Qasmiyeh \& P. Daley (eds.), Handbook of South-South Relations, London, Routledge, (forthcoming).
} 